\title{
Teaching Agricultural Science with Instructional Materials in Secondary Schools; What the Standard Deviation Explains about the Mean Achievement Scores
}

\author{
Marajos Alkali' ${ }^{1}$ Michael E. Ikehi2 ${ }^{*}$, Rose N. Okoye ${ }^{2}$ \\ ${ }^{1}$ Department of Agriculture Education, College of Education, Gidan-Waya, Kafanchan, Kaduna State, Nigeria \\ ${ }^{2}$ Department of Agricultural Education, University of Nigeria, Nsukka, Enugu State, Nigeria \\ Email: "ikehidon1@yahoo.com
}

Received 22 April 2016; accepted 23 August 2016; published 26 August 2016

Copyright (C) 2016 by authors and Scientific Research Publishing Inc.

This work is licensed under the Creative Commons Attribution International License (CC BY). http://creativecommons.org/licenses/by/4.0/

(c) (i) Open Access

\section{Abstract}

This quasi-comparative-experimental study explained student achievements scores based on the level of disparity in the means within the control and experimental groups. Four secondary schools (two-government and two-private owned) were studied in Enugu State. The study was comprised of 182 Agricultural Science students in 4 intact classes drawn from four secondary schools in Enugu state. A Student Achievement Test (SAT) was used for data collection. The instrument was faced and content validated. Kuder-Richardson formula (K-R21) was used to determine the internal consistency of the instrument after trial testing, which yielded a reliability index of 0.79. Mean and standard deviation were used for data analysis. Findings of the study strongly supported the use of instructional materials in content delivery but cautions on the diverging effects that could arise among student as revealed in the widening gap between the highest and lowest mean achievement scores.

\section{Keywords}

Achievement, Control, Experimental, Gap, Group, Scores

\section{Introduction}

Secondary schools are educational institutions below tertiary level established to inculcate in learners the socie-

${ }^{*}$ Corresponding author.

How to cite this paper: Alkali, M., Ikehi, M. E., \& Okorie, R. N. (2016). Teaching Agricultural Science with Instructional Materials in Secondary Schools; What the Standard Deviation Explains about the Mean Achievement Scores. Creative Education, 7, 1929-1934. http://dx.doi.org/10.4236/ce.2016.714195 
tal needs and values, and make them skilful. These needs, values and teachable skills are designed into bodies of knowledge and taught to learners, such as Agricultural Science. Agricultural science is largely the application of scientific principles for successful production of crops and livestock and other uses for man's benefit (Talathi, Naik, \& Jalgaonkar, 2011; Onu, Ugwoke, Agboeze, \& Ikehi, 2014).

Agricultural science, as a subject in secondary schools, seeks to teach the students the principles of using scarce resources to produce crops and animals to feed the world's population and to service other related uses (Ikehi, Ifeanyieze, \& Ugwuoke, 2014). The teaching and learning of vocational studies as well as skilled based sciences such as Agricultural Science, have often called for the use of instructional materials during content delivery to aid learners' learning pace and retention (Onu \& Ikehi, 2013).

Instructional materials are resources or teaching materials which a teacher utilizes in the course of presenting a lesson in order to make the content of the lesson understandable to the learner (Perkins, 2009; Rush, Acton, Tolley, Marks-Maran, \& Burke, 2010; Nwike \& Onyejegbu, 2013; Ikehi, Paradang, \& Zimoghen, 2014). They could be audio, video or picture or actual object being thought (Agina-Obu, 2005; Riener \& Willingham, 2010; Agbulu \& Wever, 2011; Allen, Donham, \& Bernhardt, 2011; Nwike \& Onyejegbu, 2013; Onu, Ugwoke, Agboeze, \& Ikehi, 2014). Instructional materials aid learning as well as retention and recalling (Campitelli \& Gobet, 2011; Lucas, Spencer, \& Claxton, 2012). Examples of instructional materials include, audio-visual learning displaces, living subjects and most commonly, textbooks, workbooks, charts and related items that help explain learning content (Lindberg, 2003; Laurillard, 2012; Lloyd \& Payne, 2012; Olawale, 2013). Indisputably, the use of instructional materials has yielded better results in learning especially in vocational studies, thus their widely proclaimed use. Comparing the mean scores of control groups taught without instructional materials, and experimental groups taught with instructional materials has always reported better performance from the latter than the former. However, it has always been an inter-comparison among the groups, and usually no comment on the intra-performance. Thus this study compares the level of disparity of the mean achievement scores of Agricultural Science students taught with and without instructional materials, in Enugu state.

\section{Methodology}

The study adopted quasi-comparative-experimental research design. A $2 \times 2$ non-randomized pre-test-post-test non-equivalent control group, non-factorial design was used for the study. This research design was used since the students in the study were not randomized into experimental and control groups but left intact and classified into groups in order to avoid disrupting the activities of the classes and the school programmes. Further, this is solely to keep the students in their natural learning environment/condition without tipping them off of the study on their academic achievements. The study was carried out in the Enugu Educational Zone (EEZ) in Enugu State. The penultimate students of Agricultural Science students in Enugu State served as the population of the study. The study had a sample size of182students in 4 intact classes drawn from urban senior secondary schools in the Zone. The schools were randomly selected and two among the four schools were randomly assigned as the experiment and control groups (Table 1).

A Student Achievement Test (SAT) was used for data collection. The SAT was developed from secondary school Agricultural Science curriculum. SAT was a 50-items teacher-made test structured by the researchers. The test items covered crop production (pre-planting, planting and post planting operations) and animal production (breeding, keeping, feeding and nutrition). The blueprint of the items was anchored on the six levels of cognitive educational objectives of Bloom (1968). The six levels were broken into two broad categories in accordance with the classification of students' cognitive abilities, with questions that tested students' ability at high

Table 1. Population distribution.

\begin{tabular}{cccccc}
\hline Group & School & Male & Female & Total \\
\hline \multirow{2}{*}{ Experimental } & EA & 25 & 18 & 43 \\
& & EB & 19 & 23 & 42 \\
\multirow{2}{*}{ Control } & & CA & 26 & 22 & 48 \\
& & CB & 28 & 21 & 49 \\
& & & 98 & 84 & 182 \\
\hline
\end{tabular}


and low levels of cognitive domains. Their ability to analyze, synthesize and evaluate concepts in Agricultural Science was tested at the high level. At the low-level, the questions tested students in knowledge, comprehension and application. The first and second forms of the instrument were used as pre-test (pre-SAT) and post-test (post-SAT) respectively, to measure the students' achievement in Agricultural Science topics that were taught during the study. However, the post-SAT was produced by re-arranging and re-constructing the test items in pre-SAT so as to alter its structural view but retain the same content. The topics listed to be taught during the study were divided into 4 units. Four lesson notes were planned and written on each unit to guide the research assistants (the class teachers of Agricultural Science) in the experimental and control groups. Both groups used lecture method but the experimental group involved most relevant instructional materials, which was the main difference between the two groups. For consistency and objectivity in scoring the students' SAT items, a marking scheme was developed for the pre-SAT.

The instrument was face and content validated by five experts, three experienced Agricultural Science teachers and two Agricultural Education Lecturers at the University of Nigeria, Nsukka. The experts validated the instrument and approved it for suitability and appropriateness of use. The instrument was trial tested on 20 students in Nsukka Educational Zone of the State. The result of the trial testing was used to calculate the reliability of the test instrument using Kuder-Richardson formula $\left(K-R_{21}\right)$ which yielded an index of 0.79 , indicating that the instrument was fit for use.

To conduct the study, the sampled schools were visited and permission was obtained from the principals of the schools to carry out the study. The teachers, who teach Agricultural Science in the sampled schools served as research assistants. The research assistants administered the pre-SAT test to the sampled students before lesson. The object of the pre-test was to ascertain the homogeneity of the students' experience and knowledge in Agricultural Science before the experiment. The research assistants taught the students using the lesson plan designed for their group for 4 weeks of the study. At the end of the lessons, the post-SAT was administered and the achievement in Agricultural Science computed. The marking scheme prepared by the researchers was used to score the tests for data analysis. Mean and Standard Deviation were used in data analysis. In accomplishing the research objective following was observed:

1) The mean $\left(\bar{X}_{1}\right)$ of pre-test scores was calculated for each group of students (taught Agricultural Science with and without instructional materials).

2) The mean $\left(\bar{X}_{2}\right)$ of post-test scores was calculated for each group of students (taught Agricultural Science with and without instructional materials).

3) The mean gain $\left(\bar{X}_{G}\right)$ was determined by subtracting the mean $\left(\bar{X}_{1}\right)$ of pre-test from the mean $\left(X_{2}\right)$ of post-test scores of each group. That is,

$$
\bar{X}_{G}=\bar{X}_{2}-\bar{X}_{1}
$$

4) The Achievement Outcome (AO) was estimated by subtracting mean gain ( $\bar{X}_{G}$ ) of group 1 from the mean gain $\left(\bar{X}_{G}\right)$ of group 2 .

$$
E=\bar{X}_{G_{1}}-\bar{X}_{G_{2}} .
$$

For decision making, where $E$ is:

i) positive (+), it indicated that instructional materials enhances students' achievement in the content delivered.

ii) negative (-), it indicated that instructional materials minimized students' achievement in the content delivered.

iii) zero (0), it indicated that instructional materials had no improvement on students' achievement.

\section{Results}

The results for the study were presented in Table 2.

In Table 2, the data available reveals that the students taught with instructional materials (IM) had a mean gain of 13.75 with an average standard deviation of 13.08 while those taught without instructional materials (IM) had a mean gain of 7.76 with an average standard deviation of 8.76. Comparing the achievement outcome of both groups, data on the table indicate that the mean difference is 5.99 . 
Table 2. Level of disparity of mean achievement scores of Agricultural Science students thought with and without instructional material, in Enugu state. $\mathrm{N}=182$.

\begin{tabular}{cccccccccc}
\hline Group & N & \multicolumn{2}{c}{ Pre-test } & \multicolumn{2}{c}{ Post-test } & & & \\
& & $\overline{\boldsymbol{X}}$ & SD & $\overline{\boldsymbol{X}}$ & SD & $\overline{\boldsymbol{X}}$ Gain & SD D. & Avg. SD \\
\hline With IM & 85 & 41.87 & 10.14 & 55.62 & 16.01 & 13.75 & 5.87 & 13.08 \\
Without IM & 97 & 42.15 & 9.79 & 49.91 & 11.32 & 7.76 & -2.03 & 8.76 \\
AO & & & & & & $\mathbf{5 . 9 9}$ & & $\mathbf{4 . 3 2}$ \\
\hline
\end{tabular}

IM = Instructional Materials; N = Number of Students; SD = Standard Deviation; SD D. = Standard Deviation Deference; AO = Achievement Outcome.

\section{Discussion of Results}

The results of the study in Table 2 revealed that the students of both groups can be rated as similar or same skill and knowledge level in the subject and topics they were taught as indicated by the pre-test mean achievement scores of 41.87 and 42.15 for experimental and control groups, respectively. The mean values are close with the control group value slight above that of the experimental group. The standard deviations of 10.14 and 9.79 for the pre-test further provided justification to assume that the students had equal or nearly equal level of the tested skills and knowledge. The results of the post-test revealed a positive improvement for both groups, however, the students taught with IM performed better than those taught without IM, as indicated by the mean gain of 5.99. For the control group, their group achievement mean rose from 42.15 in the pre-test result to 49.91 with a mean gain of 7.76. This achievement is thus attributable to the knowledge acquired after content delivery and possibly to the re-interaction with the test items (though the items were re-arranged), at the post-test. For the experimental group, their mean achievement score of 41.87 in the pre-test rose to 55.62 with a performance enhancement of 13.75 which nearly doubled that of the gain in the control group. Like the control group, the acquisition of acknowledge and the re-interaction of the students with the test items explained their improvement. But the better improvement of the experimental group over the control group can only be attributed to the use of IM during content delivery. The mean gain is likely a true knowledge or performance difference completely attributable to the use of the instructional materials. The findings of this study reaffirm that of Fakomogbon (2012), Igu, Ogba, \& Igwe (2014), Adebule \& Ayoola (2016) and Jekayinfa (2016), who reported that students taught with instructional materials performed better than those taught without instructional. However, some factors silent to the study might have favoured the experimental group or inhibited the control group but the difference cannot be ascribed to mere chance.

While the use of IM is worth celebrating owing to the better mean achievement score of the experimental group as revealed in this study and other studies, a look at the level of disparity through the standard deviation is worthwhile. Standard deviation in studies like this helps the researches to explain how close to each other the scores were and/or how far apart the highest score(s) was (were) from the lowest(s). Usually, the lower the value the closer the scores, the smaller the gap between high scores and low scores and thus the more convergent the level of knowledge among the students. And the higher the value the farther the scores are from each other, the higher the gap between the higher and lower scores, thus the more dispersed and divergent the level of knowledge.

As presented in Table 2, the standard deviations of the experimental and control groups were 10.14 and 9.79 in the pre-test, but were 13.75 and 7.76 in the post-test, respectively. The values of the post-test indicate that, while the control group became closer in their knowledge level by reducing their disparity level by -2.03 in their post-test making them even closer than they were in their pre-test, the level of disparity widened by 5.87 in the experimental group. On an average, the standard deviations of the pre-test and post-test for both groups were 13.08 for the experimental group and 8.76 for the control group and a difference of 4.32; meaning that the use of IM made experimental group more dispersed in knowledge level than the control group.

The students in the experimental group likely reacted to the instructional materials differently unlike the control groups that no "foreign body" was introduced to them during the lessons. Conclusively, the students taught with instructional materials learnt better than those taught without the materials but were more dispersed in response and knowledge level with an average standard deviation of 13.08 against the control group with an average standard deviation of 8.76 indicating closer knowledge level among the students. As explained by Anaekwe 
(2007), Iketaku (2011) and Uzoagulu (2011), larger standard deviation value in a primary data indicates divergent response pattern among respondents. Similarly, Marshall \& Rossman (1989), Satterly (1989) and Annum (2014), explained that the higher that standard deviation when comparing means in a generated data the more dispersed the answering pattern of the source(s) of the data.

\section{Conclusion and Recommendation}

The use of instructional materials helps the students to understand certain aspects of a subject matter that cannot easily be put into words. It often provides audio-visual and/or intractable aspect of the topic during content delivery. Based on the finding of this study, it is recommended that teachers should always make use of instructional materials, especially skill-based subjects like Agricultural Science, during content delivery. However, the instructor should ensure that the use of the instructional materials does create a more diverse learning as some instructional materials might create more confuse rather than clarification among the same students. This can be achieved by properly explaining every aspect of the instructional material and its use in the subject matter. The levels of perception, adoption and acceptability of items vary among students; therefore, leaving the IM sparsely explained could lead to individualized "perception" by the students. Thus while the use of IM made some students learn more, it could create more confusion for others.

\section{Limitations of the Study}

The study did not consider the background of the students, their academic history and their interest level for the subject rather focused on strictly the relations that exists between academic achievement and the use of instructional materials. A second limitation is the teacher/instructor factor. This was not held constant. For the four classes (2 experimental and 2 control), different research assistants (classroom teachers) were engaged. While the aim of using the regular/existing Agricultural science teachers was to keep the students and the class in the intact form, the level of performance of the teachers could different. These factors could have as well affected the result of the study in any of the groups.

\section{Conflict of Interests}

The authors did not declare any conflict of interests.

\section{References}

Adebule, S. O., \& Ayoola, O. O. (2016). Impact of Instructional Materials on Students' Academic Performance in Mathematics in Secondary Schools in Ekiti State, Nigeria. Research Journal of Educational Studies and Review, 2, 1-4.

Agbulu, O. N., \& Wever, D. G. (2011). Introduction to Vocational Agricultural Education. Makurdi, Benue State: Selfers Academic Press Ltd.

Agina-Obu, T. N. (2005). The Relevance of Instructional Materials in Teaching and Learning. In I. Robert-Okah, \& K. C. Uzoeshi (Eds.), Theories Are Practice of Teaching (pp. 9-12). Port Harcourt: Harey Publication.

Allen, D., Donham, R., \& Bernhardt, S. (2011). Problem-Based Learning. New Directions for Teaching and Learning, 128, 21-29. http://dx.doi.org/10.1002/tl.465

Anaekwe, C. M. (2007). Basic Research Methods and Statistics in Education and Social Sciences. Onitsha: Sofie Publicity and Printry Ltd.

Annum, G. (2014). Research Instrument for Data Collection. Ghana: Kwame Nkrumah University of Science and Technology.

Bloom, B. M. (1968). Learning for Mastery. Center for the Study of Evaluation of Instructional Programs, 1, 1-12.

Campitelli, G., \& Gobet, F. (2011). Deliberate Practice: Necessary But Not Sufficient. Current Directions in Psychological Science, 20, 280-285. http://dx.doi.org/10.1177/0963721411421922

Fakomogbon, M. A. (2012). Problems of Using Foreign Instructional Media in the Nigerian Environment. African Journal of Information and Technology, 1, 62-71.

Igu, N. C. N., Ogba, F. N., \& Igwe, I. O. (2014) Effects of Instructional Materials on Students’ Achievement in Social Studies in Lower Basic Education in Nigeria. Proceedings of the International Conference on 21st Century Education at Dubai Knowledge Village, 2, 37-44.

Ikehi, M. E., Ifeanyieze, F. O., \& Ugwuoke, C. U. (2014). Integration of Climate Change into the Senior Secondary School 
Agricultural Science Curriculum in Nigeria. Journal of Atmospheric and Climate Sciences, 4, 614-621. http://dx.doi.org/10.4236/acs.2014.44054

Ikehi, M. E., Paradang, S. P., \& Zimoghen, J. (2014). Utilization of Social Networks for Research by Technical and Vocational Education and Training (TVET) Students in South-Eastern Universities in Nigeria. IOSR Journal of Research \& Method in Education, 4, 25-31. http://dx.doi.org/10.9790/7388-04222531

Iketaku, I. R. (2011). Introduction to Educational Research and Statistics. Enugu: Fidgina Global Books.

Laurillard, D. (2012). Teaching as a Design Science: Building Pedagogical Patterns for Learning and Technology. London: Routledge.

Lindberg, V. (2003). Learning Practices in Vocational Education. Scandinavian Journal of Education Research, 47, 157179. http://dx.doi.org/10.1080/00313830308611

Lloyd, C., \& Payne, J. (2012). Raising the Quality of Vocational Teachers: Continuing Professional Development in England, Wales and Norway. Research Papers in Education, 27, 1-18. http://dx.doi.org/10.1080/02671522.2010.483524

Lucas, B., Spencer, E., \& Claxton, G. (2012). How to Teach Vocational Education: A Theory of Vocational Pedagogy (pp. 59-84). London: City \& Guilds Centre for Skills Development.

Marshall, C., \& Rossman, G. B. (1989). Designing Qualitative Research. Newbury Park, CA: Sage.

Nwike, M. C., \& Onyejegbu, C. (2013). Effects of Use of Instructional Materials on Students Cognitive Achievement in Agricultural Science. Journal of Educational and Social Research, 3, 103-107.

Olawale, S. K. (2013). The Use of Instructional Materials for Effective Learning of Islamic Studies. Jihat-al-Islam, 6, 29-40.

Onu, F. M., \& Ikehi, M. E. (2013). Factors Influencing Students’ Choice to Study Agricultural Science in South-South Nigeria. Journal of Agriculture and Biodiversity Research, 2, 80-86.

Onu, F. M., Ugwoke, E. O., Agboeze, M. U., \& Ikehi, M. E. (2014a). Utilization of the Interactive Whiteboard Technology for Instructional Delivery in Technical and Vocational Education and Training Courses in South Eastern Universities in Nigeria. Indian Journal of Applied Research, 4, 149-151.

Onu, F. M., Ugwoke, E. O., Agboeze, M. U., \& Ikehi, M. E. (2014b). Cost Effective Mechanisms for Mobilizing the Youths for Fish Production and Marketing in Niger Delta Region of Nigeria. African Journal of Social Sciences, 4, 36-42.

Perkins, D. (2009). Making Learning Whole: How Seven Principles of Teaching Can Transform Education. San Francisco, CA: Jossey-Bass.

Riener, C., \& Willingham, D. (2010). The Myth of Learning Styles. Change: The Magazine of Higher Learning, 42 , 32-35. http://dx.doi.org/10.1080/00091383.2010.503139

Rush, S., Acton, L., Tolley, K., Marks-Maran, D., \& Burke, L. (2010). Using Simulation in a Vocational Programme: Does the Method Support the Theory? Journal of Vocational Education \& Training, 62, 467-479. ttp://dx.doi.org/10.1080/13636820.2010.523478

Satterly, D. (1989). Assessment in Schools. Oxford: Basil Blackwell Ltd. http://www.foundationcoalition.org/home/keycomponents/assessment_evaluation.html

Talathi, J. M., Naik, G. V., \& Jalgaonkar, V. N. (2011). Introduction to Agricultural Economics and Agribusiness Management. New Delhi: Ana Book Publishers.

Uzoagulu, A. E. (2011). Practical Guide to Writing Research Project Report in Tertiary Institutions. Enugu: Cheston Publishers. 